\section{Peer Teaching Increases Knowledge and Changes Perceptions about Genetically Modified Crops in Non-Science Major Undergraduates}

Hanya E. Chrispeels, * Jordan M. Chapman, Carole L. Gibson, and Gloria K. Muday*

Department of Biology, Wake Forest University, Winston-Salem, NC 27109

\begin{abstract}
We analyzed effects of peer teaching on non-science major undergraduates' knowledge, perceptions, and opinions about genetically modified (GM) crops and their use in agriculture. Undergraduates enrolled in an introductory nonmajors biology course participated in a service-learning program (SLP) in which they acted as cross-age peer teachers to high school students, teaching about the role of genetics in crop improvement through traditional breeding and GM approaches. Using pre/postassessments, we found that undergraduates' opinions shifted to favor the use of GM organisms (GMOs) in agriculture after SLP participation, rising from 46 to $97 \%$. Perceptions about risks and benefits of GMOs also shifted from $43 \%$ stating that GMOs are harmful or suspect to no students describing GMOs in that way. Knowledge about GMOs became more accurate after SLP participation. There were significant correlations between students who had negative perceptions of GMOs and negative opinions or inaccurate knowledge about them. Students recognized the effect of peer teaching on their knowledge and perceptions, identifying the repeated peer teaching as an important factor in knowledge gain. Our results suggest students developed an informed opinion about the use of GMOs through first learning the science of genetic engineering and then teaching this information to younger students.
\end{abstract}

\section{INTRODUCTION}

One important goal of science education is to teach the science behind socioscientific issues, as well as their societal impacts and controversies, to help create a scientifically literate citizenry (Sadler, 2004; Millar, 2006; National Research Council, 2012). However, the complex concepts associated with issues such as stem cell research, cloning, and genetic engineering often act as a barrier to students, limiting their understanding of these topics. Although genetically engineered plants have been grown and used for food in the United States for more than three decades, the use of these crops is an example of a socioscientific issue about which many misconceptions still persist. These misconceptions and misunderstandings include how genetically modified organisms are generated, their prevalence and use, and their effects on the humans who consume them and the environment in which they are grown (McHughen and Wager, 2010; McHughen, 2013; Mohapatra et al., 2010). There is not even a consensus on the meaning of terms used to describe organisms produced by genetic engineering. "Genetically engineered" (GE), "genetically modified" (GM), and "genetically modified organism" (GMO) are all used to describe an organism that results from adding genes that convey novel traits as a result of biotechnology. Although the term "genetically modified" has a broader scientific definition, in this study we use it synonymously with "genetically engineered" and apply it to crops into which both plant and bacterial genes have been transferred.
Marshall Sundberg, Monitoring Editor Submitted Sep 4, 2018; Revised Jan 14, 2019; Accepted Jan 22, 2019

CBE Life Sci Educ June 1, 2019 18:ar14

DOI:10.1187/cbe.18-08-0169

*Address correspondence to: Gloria K. Muday (muday@wfu.edu) and Hanya E. Chrispeels (chrisphe@wfu.edu).

(c) 2019 H. E. Chrispeels et al. CBE-Life Sciences Education () 2019 The American Society for Cell Biology. This article is distributed by The American Society for Cell Biology under license from the author(s). It is available to the public under an Attribution-Noncommercial-Share Alike 3.0 Unported Creative Commons License (http://creativecommons.org/licenses/ by-nc-sa/3.0).

"ASCB $®$ " and "The American Society for Cell Biology $\circledR^{\prime}$ are registered trademarks of The American Society for Cell Biology. 
Surveys of undergraduate students have shown that their understanding about GMOs, like that of the general population, is incomplete or inaccurate. This incomplete understanding includes the incorrect assumptions that genes are present only in GE food (and absent in other foods), that GMOs are not tested or regulated, and that GMOs have been shown to be detrimental to human health (Sohan et al., 2002; Finke and Kim, 2003; Wingenbach et al., 2003; Tegegne et al., 2013). Furthermore, studies have identified disparities between students of different academic backgrounds in their knowledge and attitude toward biotechnology, including GMOs (Fonseca et al., 2012; Tegegne et al., 2013). Tegegne and colleagues (2013) found that college students studying physical and biological science were more knowledgeable about, and more favorable toward, the use of agricultural biotechnology than students majoring in a social science. Thus, students who are not majoring in natural science are an especially important audience for teaching about socioscientific issues and correcting misconceptions and misunderstandings.

Studies that measure knowledge about and attitude toward biotechnology before and after an intervention have shown that a positive attitude about the use of biotechnology is generally correlated with correct knowledge about biotechnology and that the prevalence of positive attitudes generally increases as knowledge increases (Santerre and Machtmes, 2002; Klop et al., 2010; Heddy et al., 2016). Santerre and Machtmes (2002) studied the effect of lecture presentations about the use of GMOs in agriculture on knowledge and attitudes about GMOs, examining a range of study groups, including science major and non-science major undergraduates, graduate students, and different types of community members. They found that knowledge about GMOs increased and attitudes toward their use became more positive after instruction in all groups, except for cooperative extension educators, for whom knowledge was already high and attitudes were already positive. Heddy and colleagues (2016) found that when undergraduates read a refutation text about GMO-derived foods (a text that teaches about a topic by directly challenging one or more misconceptions and providing the correct conceptions), not only did their knowledge increase, but their positive emotions and favorable attitudes about the use of GMOs also increased. In the study by Klop et al. (2010), the attitudes of secondary students about biotechnology (including GMOs and other forms of biotechnology) changed after participating in a lab activity module about cancer research. The percentage of students who were labeled as "confident supporters" of biotechnology was higher for students who had participated in the module compared with the control group, whereas more students were identified as skeptical, unsure, or opposed to the use of biotechnology in the control group compared with the treatment group.

Not all studies have found that changes in attitude accompany increased knowledge. In surveys of European adults, no correlation exists between knowledge about GMO-derived foods and positive attitudes toward their use, but both strong positive and negative attitudes are found to occur when knowledge is lacking (Bredahl, 2001; European Commission, 2001; Wohl, 1998). The latter finding suggests that a favorable stance toward a controversial subject can be formed even if knowledge is faulty. In a study of Australian high school students, Dawson and Soames (2006) found that students' attitudes about the use of genetic engineering depended on the organism involved and that attitudes toward the use of microorganisms or plants were highly positive before instruction and did not change after instruction. However, their survey asked about the potential use of genetic engineering for crop improvement, rather than about existing GE crops.

Studies examining changes in biotechnology-related knowledge and attitudes have used various types of interventions to increase knowledge, but none have used peer teaching as the method of intervention. Lectures (Santerre and Machtmes, 2002), refutation texts (Heddy et al., 2016), hands-on lab activities (Klop et al., 2010; Witzig et al., 2013), and case studies (Dori et al., 2003) all have been shown to impact knowledge and attitudes. In this study, we chose to examine an active-learning strategy of peer teaching, as it had the added benefit of bringing college students into high school classrooms. Crossage peer teaching, also called cross-age teaching or near-peer teaching, is defined as older students teaching younger students and is considered a form of peer teaching, because the teachers are still students themselves, rather than professionals (Gaustad, 1993; Robinson et al., 2005; Topping, 2005; Korner and Hopf, 2015). Cross-age peer teaching has been shown to have positive learning outcomes for both the teaching and learning peers in many subjects (Cohen et al., 1982; Juel, 1991; Topping, 1996; Robinson et al., 2005; Roscoe and Chi, 2007; Galbraith and Winterbottom, 2011; Korner and Hopf, 2015). Cross-age and same-age peer teaching are used extensively in medical schools (e.g., see reviews by Yu et al., 2011; Burgess et al., 2014), but less consistently at the undergraduate level. Several studies of undergraduates have found that students who teach achieve higher test scores than students who learn material with no expectation of teaching or only for the purpose of taking a test (Bargh and Schul, 1980; Annis, 1983; Benware and Deci, 1984; Fiorella and Mayer, 2013). These studies involved students who tutored one-on-one or who gave a presentation to a video camera, rather than students teaching a group of younger students in a classroom setting.

The effects of cross-age peer teaching specifically on undergraduate students enrolled in biology and chemistry courses and acting as teachers to younger students have been assessed using reflective writing assignments, surveys, and questionnaires, and multiple cognitive and affective gains have been identified. Affective gains include increased personal skills (Esson et al., 2005; Begley, 2013), a feeling of personal reward (Robinette and Noblet, 2009), and connection to the community (Robinette and Noblet, 2009; Begley, 2013; Glover et al., 2014). Cognitive gains include greater increases in test scores for peer-taught concepts compared with concepts learned only in lecture (Tessier, 2007; Chrispeels et al., 2014), and an increased ability to design experiments (Esson et al., 2005). In addition, peer teachers perceive an increase in their own learning after participating in peer teaching (Juel, 1991; Topping, 1996; Galbraith and Winterbottom, 2011; Chrispeels et al., 2014).

Why the teaching peers obtain cognitive and affective benefits from teaching is not completely understood, and several ideas have been proposed to explain the observed benefits (Ten Cate and Durning, 2007). Bargh and Schul (1980) suggest that the preparation stage of teaching results in a differential organization and processing of the material to be taught that produces 
cognitive gains for the teaching peer. Annis (1983) suggests that the teaching peer learns more as a result of the three-step theory of verbal learning, a process that involves students paying attention to the material, processing it in a way that is meaningful, and then associating the material with what the student peer already knows. Role theory is another psychological theory that can explain both cognitive and affective benefits of peer teaching (Allen and Feldman, 1972, 1976). When individuals take on a certain role, they adopt behaviors associated with that role. When students take on the role of teachers, the behaviors associated with being a teacher can increase feelings of self-efficacy and self-confidence and lead to students perceiving themselves as experts. It may also increase learning by motivating the teaching peer to learn the material to avoid embarrassment and to be able to answer questions (Galbraith and Winterbottom, 2011).

Benware and Deci (1984) propose that learning material to teach it activates an individual's intrinsic motivation, which is a person's inherent tendency to learn and be engaged in the absence of external reward. According to self-determination theory, intrinsic motivation is supported when one experiences certain psychological conditions: autonomy (sense of choice), competence (sense of mastery), and relatedness (sense of connection; Deci and Ryan, 1985; Ryan and Deci, 2000). A large body of literature has provided empirical evidence that students who learn in environments that support these three conditions have increased cognition, motivation, and interest in the subject material (e.g., Pintrich, 2003; Minnaert et al., 2007; Guay et al., 2008; Niemiec and Ryan, 2009; Beachboard et al., 2011). In terms of peer teaching, learning the material well enough to explain it to others, feeling like an expert vis á vis the student peers, making decisions about how to best teach the material, and other aspects of the teaching process could all lead to fulfillment of these three conditions.

To our knowledge, no one has used cross-age peer teaching as a method of intervention for examining changes in attitudes about a socioscientific issue. Previously we examined the effect of a peer-teaching model on cognitive gains in understanding principles of genetics (Chrispeels et al., 2014). In the present study, we used the same model to determine not only whether knowledge increases, but also whether teaching results in changes in attitudes toward and perceptions of a socioscientific issue, specifically the use of GMOs in agriculture. In this study, we identified opinions and perceptions about GMOs held by non-science major undergraduates and determined how and why those changed after students participated in a cross-age peer-teaching program in which the undergraduates taught a lesson about plant biology, genetics, and crop improvement to students in local high schools. We also examined how undergraduates' knowledge about plant reproduction, plant anatomy, genetics, GMOs, and crop improvement changed after participating in the peer-teaching program. The purpose of the lesson was to help students understand the extent to which food has been modified over millennia by the various technologies available to farmers, and how valuable traits are introduced into crop plants via selective breeding and genetic engineering. These concepts were framed in the context of drought, an important agricultural problem, to illustrate how mutations and genetic modifications that improve drought toler- ance are valuable tools for improving crops and solving agricultural problems. Our research questions were

1. What are students' opinions as to whether GMOs should be used as food, and do those opinions change after peer teaching?

2. What perceptions do students have about the risks and benefits of GMOs? Are those perceptions affected by peer teaching?

3. Do students have accurate knowledge about GMOs before the peer-teaching program, and how does that knowledge change as a result of peer teaching? Is the change in knowledge linked to changing perceptions and opinions?

4. Do students obtain or use information about GMOs more frequently after peer teaching?

\section{METHODS}

Study Design

Participants in this study were undergraduates attending a private, liberal arts institution with an undergraduate student enrollment of $\sim 5100$. The students in this study were enrolled in a non-science majors' course that counts toward the university's math and natural sciences graduation requirements. The course, BIO 101: Biology and the Human Condition, was an issues-based introductory biology course that consisted of three 1-hour lecture periods, taught by one of the authors (C.L.G.), and one 3-hour lab session per week. The course curriculum includes the basic principles of biology as well as recent advances and their ethical, social, and political implications. Most students in this class were first- or second-year students who had not yet declared a major but who were not planning to major in a science at the time of enrollment. The cohort consisted of 49 students: $56 \%$ male and $44 \%$ female; 59\% freshmen, $31 \%$ sophomores, $2 \%$ juniors, and $8 \%$ seniors.

Undergraduates enrolled in the course participated in a 3-week service-learning program (SLP) during the lab portion of the course. We used the pedagogical model of cross-age peer teaching (older students teaching younger students) in this SLP. We have successfully implemented this SLP model in this nonmajors' course for 4 years, but with a different lesson (Chrispeels et al., 2014). In the first week of the SLP, undergraduates were asked to master an active-learning lesson that was designed to meet and supplement state standards for genetics and biotechnology concepts for high school biology courses and that was written at a level appropriate for high school students. Faculty (defined as professors or graduate students associated with the SLP) taught the lesson to the undergraduates during a lab session by guiding them through the activities. This exercise used a question-and-answer method to probe students' prior knowledge and to help students comprehend new concepts. The faculty taught the training section in pairs, which modeled how the undergraduate students would lead high school students through the lesson. Undergraduates practiced the activities with their lab partners to become comfortable in explaining the concepts and carrying out the activities and were encouraged to spend time outside the lab session to increase familiarity with the activity script and the content information. Information about how to prepare for the teaching experience and what to do when in the classroom to address students' needs was also provided. College-level lectures about genetics and GMOs were 
given in the lecture portion of the class before the week of the lab training, but these lectures contained additional content and did not repeat the exact content of the lesson.

In the second and third weeks of the SLP, undergraduates traveled to local high schools and taught this same lesson to students in one or two classes at each school. Pairs of undergraduates led groups of six to 10 high school students through the lesson in the same manner as modeled in the training sessions, and teaching pairs remained the same as training pairs from the initial week whenever possible. This repeated teaching opportunity in two sequential weeks was a central feature of this SLP project. Project faculty accompanied the undergraduates, helped with setup of materials, introduced the undergraduates, and sometimes taught a group of students on their own if there were an insufficient number of undergraduate student pairs for the size of each high school class to maintain a consistent small group size.

\section{Lesson Content and Activities}

We previously demonstrated that this peer-teaching model improved students' content knowledge of basic genetic principles and molecular biology approaches (Chrispeels et al., 2014). However, our analysis of students' reflective writing revealed that the lesson did not translate to students' understanding of how plant genetics is central to agriculture, an important goal for this SLP. Thus, in 2015, we changed the lesson to build to an explanation of how crop improvement occurs both through traditional breeding and genetic engineering techniques. A complete lesson description and materials are available at http:// muday.sites.wfu.edu/outreach. The format of the lesson is designed so that the undergraduates use pictures and diagrams to introduce concepts, ask questions of the high school students about those concepts, and lead them through hands-on activities. These activities include card sorting, card matching, extracting DNA from tomatoes, and completing Punnett squares, among others. These activities were designed to provide engaging ways of teaching the content to the high school students.

The lesson began with a card-matching activity that illustrated the dissimilarity between modern crop plants and their wild ancestors to emphasize that humans have been doing plant selection and breeding for thousands of years. The lesson then transitioned to introducing the concept of mutations and their ability to convey selective advantage in certain environmental conditions. The recent 6-year drought in California was used as the context to show how global climate change will have an effect on agricultural systems, like the important tomato industry in California, and why crop improvement is continuously necessary. Students were then taught how plants take up water via roots and lose water via transpiration, to connect the plant physiology to potential mutations that might improve crop performance under drought conditions. This set the stage for the introduction of how plants reproduce, taught via a card-sorting activity, and the Mendelian inheritance of traits, taught by using inheritance diagrams and Punnett squares. The final part of the lesson was designed to have students put these pieces together to understand how traditional crop breeding is performed and how GMO technology compares with traditional breeding. The prevalence of GM plant products in our food supply was discussed, and students were offered GM and non-GM corn chips to eat as a way of directly comparing food products resulting from the two different crop-improvement strategies. This led to a discussion of what students had read or heard about the pros and cons of GMO food, with an opportunity to clarify any misconceptions. At the end of the lesson, students were given a handout (provided in the Supplemental Material) with frequently asked questions and answers about GMOs and a list of websites containing further information about crop improvement, plant breeding, modern agriculture, genetic engineering, and GMO safety.

One goal with this lesson is to address core issues identified by others as concerns about GM crops. These include addressing discomfort with human intervention in plant genetics by emphasizing that most of our current foods reflect such intervention via selection and breeding. In the lesson, and in all assessments used in the study, the terms "genetically engineered" (GE) and "genetically modified" (GM) were used to describe the process by which genes from one organism are inserted into the genome of another organism, using molecular biology techniques, to introduce novel traits to the recipient organism. The term "genetically modified organism" (GMO) was used to describe an organism that resulted from having novel traits introduced into it by biotechnology.

\section{Data Collection}

Data for this study were collected during the Fall semester of 2016. One of the goals of this ongoing SLP is to offer the program to as many high school students as possible; therefore, all undergraduates participated in the cross-age peer teaching as a course requirement to maximize the number of high school students served. This goal led us to use a pre/postassessment approach rather than have control groups. The research was approved by the university's institutional review board (IRB00018129). Following university protocol for human subjects' research, undergraduates agreed to participate in this study by signing a consent form before the SLP. Participation in the research study was voluntary; undergraduate students' grades in the lab and lecture were not affected by their choice to participate in the research study, and none of the assessments from the study were used to calculate course grades. Students were continually reminded that completing assessment and survey instruments was voluntary. Assessment and survey instruments were made anonymous before they were analyzed. Forty-nine students signed a consent form, but eight of those dropped the class before the SLP began, and not all remaining students completed all assessments. Only data from students who responded to all phases of an assessment were analyzed, meaning both pre- and post-SLP instruments, or pre-, post-, and end-of-semester instruments (depending on the assessment).

\section{Content Knowledge Test and Opinion Survey Instrument}

Undergraduate students' knowledge of lesson content, opinions about GMOs and biotechnology, and behavior related to accessing and using information about GMOs were assessed using a three-part instrument distributed via the online survey platform Qualtrics. The complete instrument is supplied in the Supplemental Material. This assessment was given three times: before the SLP training week, after the final school teaching session, and at the end of the semester, approximately 7 weeks after the final school teaching session. The pre-SLP assessment occurred 
before college-level lectures about genetic engineering were given in the lecture portion of the course. Development of this instrument began in 2015, when the SLP lesson was changed from the original form (Chrispeels et al., 2014; Klosterman et al., 2014) to the version used in this study. The new lesson uses drought as the real-world problem to frame the genetic concepts and now includes activities related to crop improvement, plant breeding, and plant genetic engineering (instead of molecular biology techniques as in the first version).

The first part of the content knowledge assessment instrument contained 13 multiple-choice questions designed to test undergraduates' knowledge about concepts presented in the lesson, including how plants take up water, plant reproduction, plant breeding, genetics, and the use of genetic engineering in agriculture. The questions were developed in 2015 by two of the authors who are experts in these fields (H.E.C. and G.K.M.), reviewed by the two other authors (J.M.C. and C.L.G.), and used in the 2015 SLP. After analysis of the 2015 data (not used for this study), questions were revised for the 2016 cohort to better reflect the content of the lesson and improve the detractors. After revision, the questions were then given to a group of undergraduate students who were enrolled in a plant physiology and development course taught by one of the authors (G.K.M.) but were not part of the study group. The students completed the questions on their own and then participated in individual discussions with team members to determine whether students interpreted the questions as intended. Further revisions were made to the multiple-choice questions as a result of these discussions. Therefore, these questions were validated by use in a BIO 101 class and a detailed think-aloud discussion process with more advanced biology major students.

Significant differences between pre-SLP, post-SLP, and end-of-semester scores for individual questions were determined using Cochran's $Q$ test followed by post hoc analysis using McNemar's test with Bonferroni correction. These statistical tests were used because we were comparing the same group of students examined at three times with binomial data (correct or incorrect answer). For determination of how scores within each of the three question topic groups (plant biology, genetics, and GMOs) changed over time, correct answers for individual questions in each group were summed, and mean \pm SD for each topic group was determined. Repeated-measures analysis of variance (ANOVA) with Bonferroni correction was used to determine significant differences between mean scores for preSLP, post-SLP, and end-of-semester assessments. ANOVA was used because we were comparing three matched groups containing data from a Gaussian population.

The second part of this instrument contained a statement about GMOs: "Genetically engineered crop plants should be a part of our food supply. Do you agree or disagree with this statement? Explain your answer." On the posttest, students were also asked whether the SLP-related experiences in BIO 101 affected their answer. Opinion responses to the statement about GMOs were scored as agree, conditionally agree, uncertain, or disagree. Open-format responses were analyzed by using inductive coding, the process of conceptualizing and categorizing qualitative data (Corbin and Strauss, 2008). In inductive coding, categories are determined after reading through the raw data, rather than being determined before reading the data. Thus, rather than assuming ahead of time that students had particular perceptions of or degrees of knowledge about GMOs, we used the raw data to determine what those perceptions or degrees of knowledge were. Three authors (H.E.C., J.M.C., and G.K.M.) read the responses and then formulated categories based on the responses. Those authors then reread the responses and sorted them into the categories. This process was done twice to code the comments into two sets of categories.

The first set of categories was based on the students' perceptions of GMOs, and included the categories harmful, suspect (of dubious value), benign (neither harmful nor beneficial), beneficial, and indispensable (society cannot exist without them). Initial interrater reliability for this coding was determined using an intraclass correlation coefficient; ICC $=0.871$. Subsequent discussion resulted in $100 \%$ consensus.

The second set of categories was concerned with the students' degree of knowledge that informed their perceptions of GMOs. These categories were incorrect knowledge, incomplete understanding, and accurate knowledge. Comments were coded as incorrect knowledge if they included statements about GMOs not based on scientific fact. If a student noted the existence of a GMO with a certain trait that is not commercially available to farmers or consumers, we coded that comment as based on incomplete understanding. If a student stated the potential for GMOs to have a certain trait in the future and the trait was scientifically feasible, we coded that comment as accurate knowledge. Initial interrater reliability for this coding was determined using an intraclass correlation coefficient; ICC $=0.860$. Subsequent discussion resulted in $100 \%$ consensus. A two-tailed Fisher's exact test, followed by post hoc pairwise analysis with Bonferroni correction, was used to determine whether a correlation existed between opinions about the use of GMOs and perceptions of GMOs and between perceptions and degree of knowledge. This statistical test was used because we were comparing three unmatched groups of categorical data, but some sample sizes were too small for a chi-square analysis.

The third part of the instrument contained three questions about how frequently students accessed or used information related to GMOs. Students answered on a four-point scale: never, rarely, sometimes, and often, a scale designed to reflect what were the most probable frequencies for student responses. Such a scale often includes "always," but that seemed an inappropriate option for questions about frequency of reading a website. A fourth question asked students to explain in an open-response format about their retrieval and use of GMO-related information. Reliability analysis determined that Cronbach's alpha for this survey portion of the assessment was $\alpha=$ 0.82. A Friedman's test followed by a Wilcoxon signed-rank analysis was used to determine significant differences for response distributions between assessment times. These statistical tests were used because we were comparing three matched groups of ranked data. All statistical analysis was performed using SPSS v. 24 software.

\section{Reflective Writing Assignments}

Undergraduates were asked to write a one- to two-page reflection about their peer-teaching experiences. Reflection is an essential component of service learning and distinguishes it from other types of community service (Karyan and Gathercoal, 2005; Levesque-Bristol et al., 2010). Students were asked to reflect on and discuss their feelings about the lesson and their 
preparation to teach; their experiences interacting with the high school students; their interactions with their lab partners; whether and how the teaching experience changed their understanding of the concepts taught; and whether and how the teaching experience changed their perceptions of GMOs. Exact prompts are listed in the Supplemental Material. Reflections were read multiple times, and comments about students' perceptions about how the teaching experience affected their learning and opinions about GMOs were recorded and quantified. The process of inductive coding was used to identify aspects of the SLP that contributed to students' increase in knowledge about the lesson topics and changes in perceptions of GMOs. One author (H.E.C.) read the reflections and then formulated categories based on student comments. That author and another author (G.K.M.) then reread the reflections and sorted the comments into the categories. Initial interrater reliability for this coding was determined using an intraclass correlation coefficient; ICC $=0.915$. Subsequent discussion resulted in $100 \%$ consensus.

\section{RESULTS}

\section{Favorable Opinions about the Use of GMOs for Food Increased after Peer Teaching}

This study examined three intertwined features of students' thinking about GMO crops. We wanted to understand their opinions of whether GMO crops should be used as food, their perceptions of the risks and benefits of GMOs, and their knowledge of the technology used to create GMOs. We examined undergraduate students' opinions about use of GMOs in agriculture by asking students to respond to the question "Genetically engineered crop plants should be a part of our food supply. Do you agree or disagree with this statement? Explain your answer." Students answered this question before and after participating in the peer-teaching SLP. Phrasing the question in this way allowed students to have an opinion about the use of GMOs distinct from their own personal feelings about whether or not to eat GMOs themselves.

Before SLP participation, 46\% agreed with the statement that GMOs should be part of our food supply, 27\% disagreed, and $11 \%$ responded that they were uncertain (Figure 1). We placed the remaining student responses that indicated conditional agreement in a separate category, which comprised $16 \%$. These students agreed that GMOs should be used as long as certain conditions were met, such as if GMOs were safe for human consumption or safe for the environment. We separated these students into a different category from "agree," because their responses provided insight into students' perceptions about the technology, suggesting that these students did not know whether GMO crops were safe. After SLP participation, 97\% agreed with the statement that GMO crops should be part of the food supply, and 3\% (1 student) conditionally agreed. That student had previously disagreed with the statement, thus his/her opinion did change after peer teaching. Another student commented that although he/she agreed with the statement, he/she personally would not eat foods from GMO crops.

\section{Students Recognized That SLP Participation Affected Their Opinions of GMOs}

On the post-SLP assessment, we asked students whether their answer to the question on the use of GMOs was affected by

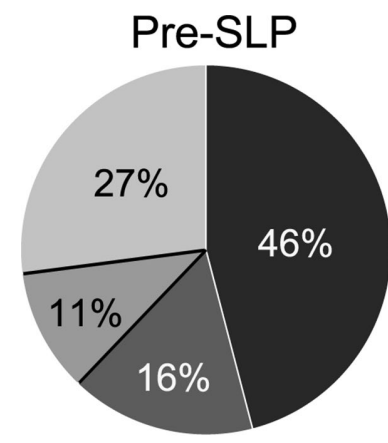

Disagree
Uncertain

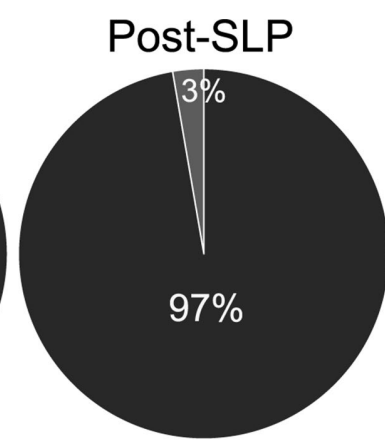

Conditionally Agree Agree
FIGURE 1. Effect of SLP on students' opinions about whether GMOs should be part of our food supply. Percentage of student responses to the statement "Genetically engineered crops should be a part of our food supply," before and after SLP participation $(n=37)$.

their SLP-related experiences. Overall, $72 \%$ of the students reported that the SLP affected their answer, and 28\% reported no effect of the SLP. To further understand the role of the SLP in affecting students' opinions, we compared the students' opinions about the use of GMOs on the pre-SLP assessment with whether or not they reported an effect of the SLP on their answer. We found that out of all the students who disagreed with or were uncertain about the use of GMOs on the pretest, $86 \%$ reported that the SLP had affected their answer on the posttest. Similarly, out of all of the students who agreed or conditionally agreed with the use of GMOs on the pretest, 64\% reported that the SLP had affected their answer on the posttest. Thus, both groups were affected by SLP participation, regardless of their opinions beforehand.

Comments elaborating on whether or not the SLP affected students' opinions about the use of GMOs indicated that, even when students originally agreed with the use of GMOs on the pre-SLP assessment, their knowledge of GMOs was strengthened, reinforcing their original opinion. For example, one student said, "Yes, I am more educated on the facts of GMOs than I was before making me more comfortable with them," and another student commented, "Yes-I am more open to them, although I was never against GMOs." Even more striking were the comments from students who originally were against the use of GMOs. One student wrote, "Yes, I am less skeptical about GMO's [sic] now, as I know that they are not all bad," and another said, "Yes. Learning about GMOs by teaching [the SLP lesson] helped me understand their purpose."

Comments from the students who agreed with the use of GMOs on the pre-SLP assessment and reported that the SLP did not change their opinion indicated that these students had learned about GMOs previously. Examples include, "Not particularly, I have always believed that genetically modified foods were good due to their prospects. Now I just have confirmation," and, "No. I had previously learned about GMO crops and their benefits in a previous science class." Evaluation of the comments from the students who disagreed with GMOs being in our food supply in the preassessment and who agreed with their use in the postassessment, but who said that their answer was not affected by the SLP, indicated that, in fact, these 
TABLE 1. Examples of student comments prior to the SLP revealing perceptions of risks or benefits of GMOs from responses to the statement "Genetically engineered crop plants should be part of our food supply"

\begin{tabular}{|c|c|}
\hline Perception category & Comment \\
\hline Harmful & $\begin{array}{l}\text { "Disagree because it is extremely harmful to the environment as well as human consumption." } \\
\text { "I disagree with this statement because I have been taught/told that genetically engineered plants can cause harm to our } \\
\text { bodies, which are not used to the unnatural ingredients." }\end{array}$ \\
\hline Suspect & $\begin{array}{l}\text { "I only agree with the above statement when GE crop plants are approved by the FDA before being distributed into the } \\
\text { food market. Without an approval by the FDA there are too many risks posed to the consumer to buy this product." } \\
\text { "I'm not sure if I agree or disagree. I know there's a lot of controversy surrounding GMOs. I kind of think I don't want } \\
\text { them in my food supply because I feel like I've heard that they aren't necessarily the healthiest things to have in your } \\
\text { food." }\end{array}$ \\
\hline Benign & $\begin{array}{l}\text { "If it would be beneficial to our society then, yes." } \\
\text { "I agree with this statement if GMO's [sic] are found to be healthy." }\end{array}$ \\
\hline Beneficial & $\begin{array}{l}\text { "I agree with this statement. They can help with food production around the world." } \\
\text { "Agree. GMOs can create crops that yield a ton more food given the same amount of space as non-GMOs, it only makes } \\
\text { sense that we take advantage of this science." }\end{array}$ \\
\hline Indispensable & $\begin{array}{l}\text { "I agree, because if we don't genetically modify crops then we could run out of food for the human race. It is necessary } \\
\text { for our sustainability." } \\
\text { "Agree. They make up such a large portion of our food supply, taking them away would be detrimental." }\end{array}$ \\
\hline
\end{tabular}

students were influenced, because their answers changed completely between the pre- and post-SLP assessments. These results suggest that the peer-teaching experience informed students' opinions about the use of GMOs, leading to a change to a positive opinion.

\section{Perceptions about Risks and Benefits of GMOs Changed after SLP Participation}

Our second research question focused on determining what perceptions the students held about the risks and benefits of GMOs, and whether or not those perceptions changed after peer teaching. We determined perceptions by analyzing the students' responses to the statement "Genetically engineered crop plants should be a part of our food supply. Do you agree or disagree? Explain your answer." Student comments were coded depending on whether they perceived GMOs as harmful, suspect (i.e., dubious), benign, beneficial, or indispensable (i.e., civilization cannot do without them) before and after SLP participation. Examples of comments from student pre-SLP responses for each category are shown in Table 1 . These perceptions were more complex than the agree/disagree analysis described earlier. As shown in Figure 2, before SLP participation, 24\% of students felt that food containing GMO ingredients were harmful and $21 \%$ of students were suspicious of GMOs. Afterward, no students thought that GMOs were harmful or suspect. At the other end of the spectrum, before the SLP, 9\% of students felt that GM crops were indispensable, saying things like, "If we don't genetically modify crops then we could run out of food for the human race." After the SLP, no students thought that GMOs were indispensable. After the SLP, 71\% of students perceived GMOs as beneficial to agriculture, and the remaining 29\% perceived GMOs as benign (neither harmful nor beneficial). Thus the peer-teaching experience resulted in students' perceptions shifting from concern about the potential harm to either neutral or focused on the potential benefits of GMOs.

As shown in Figure 3, there was a significant correlation between students who disagreed with the use of GMOs and those who perceived them as harmful or suspect before the SLP
(Fisher's exact test followed by post hoc pairwise comparison with Bonferroni correction; $p=0.0002$ ). There was also a significant correlation between students who agreed with GMO use and those who thought GMOs were beneficial ( $p=0.0002)$. These results show that students' opinions are tied to their perceptions of GMOs.

Knowledge about GMOs Increased after SLP Participation Our third research question asked whether student knowledge about GMOs and other curricular concepts increased through SLP participation. We were interested in the degree of student knowledge about GMOs and what aspects of GMO applications in agriculture were misunderstood. We were also interested in the link between perceptions of GMOs and knowledge about them. We assessed this knowledge in two ways: by a multiple-choice test and by analyzing students' comments related to their opinions of GMO use in agriculture.

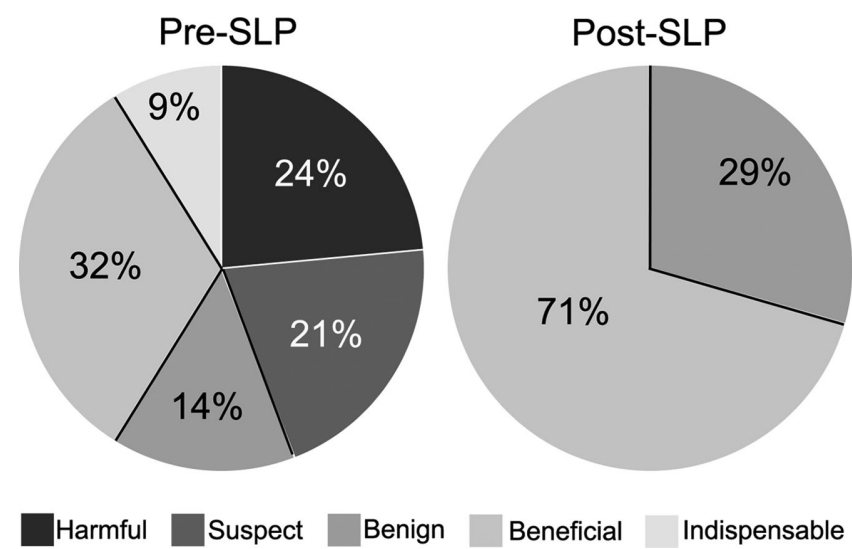

FIGURE 2. Effect of SLP on students' perceptions of the benefits and risks of GMOs. Percentage of comments indicating students' perceptions of GMOs, from responses to the statement "Genetically engineered crop plants should be part of our food supply," before and after SLP participation $(n=37)$. 


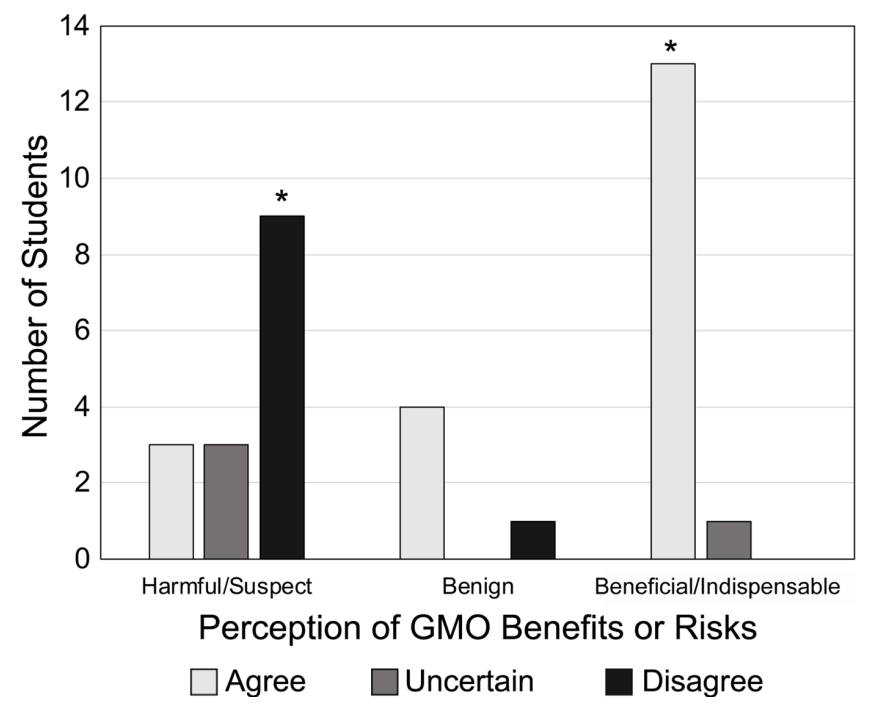

FIGURE 3. Students' opinions of the use of GMOs in agriculture as a factor of perception of benefit/risk before participation in the SLP. Number of students who agreed, were uncertain, or disagreed with the statement "Genetically engineered crop plants should be part of our food supply," and who perceived GMOs as harmful/ suspect, benign, or beneficial/indispensable. Asterisks indicate significant correlation between students who perceive GMOs as harmful/suspect and who also do not believe they should be part of our food supply and between students who perceive GMOs as beneficial or indispensable and do believe they should be part of our food supply, as determined by a Fisher's exact test followed by pairwise comparison with Bonferroni correction; $p=0.0002$ $(n=37)$.

We assessed knowledge with a 13-question multiple-choice test given before the SLP, after the SLP, and at the end of the semester, 7 weeks post-SLP. Questions covered topics of genetics, plant biology, and GMOs (see the Supplemental Material for questions). As shown in Figure 4A, the scores for all three topic areas increased over the course of the semester. Significant differences between pre-SLP and end-of-semester scores, as determined by repeated-measures ANOVA with Bonferroni correction $(p<0.05)$, were found for all three topic sets. Significant differences were found between pre-SLP and post-SLP scores and between post-SLP and end-of-semester scores for the genetics and GMO topic sets. Figure 4B shows the percent of students with correct answers for the four individual GMO questions; each is numbered to correlate with the questions reported in the Supplemental Material. Scores increased throughout the semester, with significant increases in scores between the pre-SLP and post-SLP assessments for one of the questions and between pre-SLP and end-of-semester assessments for three of the questions. (Scores for question 10, about the prevalence of GM corn and soybeans in the United States, did not show any significant increases, but were already at $90 \%$ on the pre-SLP assessment, consistent with students being previously aware of the prevalence of GMOs.) These results show that students were much less knowledgeable about the differences between selective plant breeding and GM approaches and how these are used to improve crop plants before the SLP and suggest that education that focuses on both crop improvement practices may lead to more profound attitude changes.
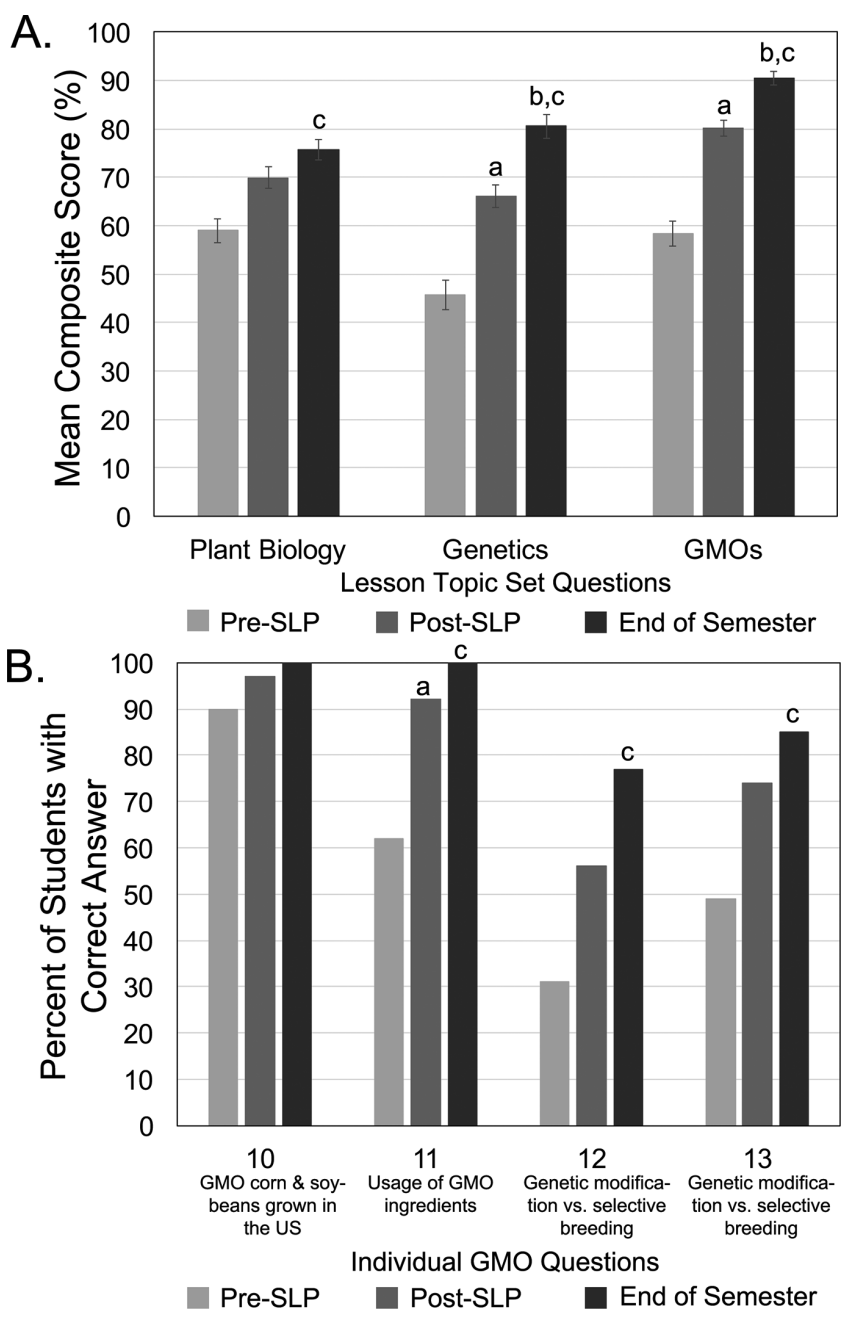

FIGURE 4. Effect of SLP participation on curricular content knowledge. (A) Mean composite score for each topic set of questions on pre-SLP, post-SLP, and end-of-semester assessments. (B) Percent of students with correct answer for each of the individual questions in the GMO topic set. Numbers below $x$-axis correlate with the questions reported in the Supplemental Material. Letters above columns indicate significant differences as determined by repeated-measures ANOVA; $p<0.05$ : a, significant difference between pre- and post-SLP assessments; $b$, significant difference between post-SLP and end-of-semester assessments; c, significant difference between pre-SLP and end-of-semester assessments $(n=37)$.

The second way we measured changes in knowledge was by analyzing student comments in response to the question "Genetically engineered crop plants should be a part of our food supply. Do you agree or disagree with this statement? Explain your answer." Responses were coded for whether they contained accurate knowledge, incomplete understanding, or incorrect knowledge about GMOs. Before the SLP, the majority of comments (53\%) contained incomplete understanding about GMOs, showing that students had some knowledge about GMOs, but it was not completely accurate (Figure 5). For example, students confused GMOs with modern agricultural practices that are not specific to the use of GE plants. Other examples of incomplete understanding were an exaggeration of the 


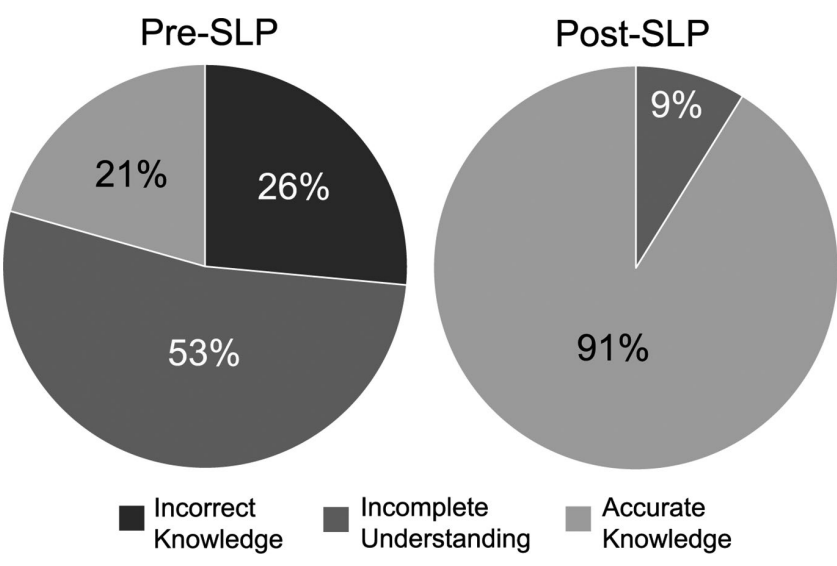

FIGURE 5. Effect of SLP on students' degree of knowledge about GMOs. Percent of comments containing incorrect knowledge, incomplete understanding, or accurate knowledge about GMOs in response to the statement "Genetically engineered crop plants should be part of our food supply," before and after SLP participation $(n=37)$.

benefits of GMOs or confusing the potential of GMOs with what is actually available commercially. Before the SLP, $26 \%$ of student responses contained incorrect knowledge about GMOs, such as GMOs contain harmful chemicals, are harmful to human health, or are harmful to the environment.

To further understand the role that knowledge had on students' perceptions about GMOs, we compared the distribution of the degree of knowledge with how students perceived GMOs before the peer-teaching experience, as shown in Figure 6. We

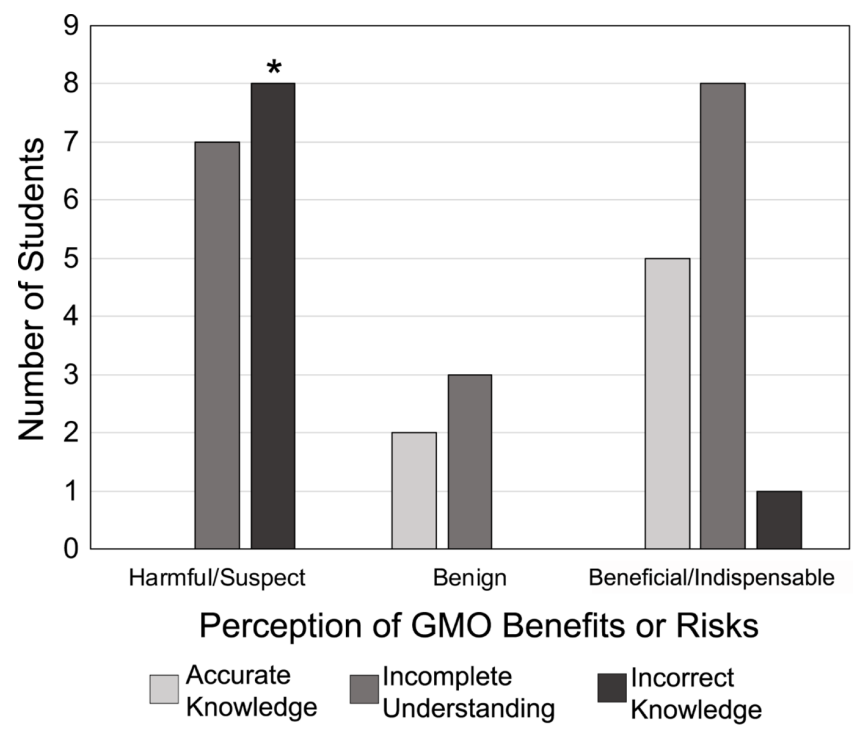

FIGURE 6. Student knowledge of GMOs as a factor of perception of benefit/risk. Number of students whose pre-SLP responses indicate accurate knowledge, incomplete understanding, or incorrect knowledge of GMOs who perceive GMOs as harmful/ suspect, benign, or beneficial/indispensable. Asterisk indicates significant correlation between students with incorrect knowledge of GMOs who perceive them as harmful or suspect, as determined by a Fisher's exact test followed by pairwise comparison with Bonferroni correction; $p=0.0014(n=37)$. found a significant correlation between perception and degree of knowledge (Fisher's exact test; $p=0.005$ ). Pairwise post hoc analysis with Bonferroni correction showed a significant correlation for students who perceived GMOs as harmful or suspect and those whose responses contained incorrect knowledge ( $p=0.0014)$. None of the students who perceived GMOs as harmful or suspect had accurate knowledge in their responses.

Figure 5 also shows the positive impact of SLP participation on student's knowledge. Comments with accurate knowledge increased from 21 to $91 \%$ after the peer-teaching experience, suggesting that students' understanding about GMOs and their applications improved. After the SLP, only $9 \%$ of the comments still contained evidence of incomplete understanding, and there were no comments that contained incorrect knowledge. These results indicate a strong positive effect on student knowledge as a result of SLP participation.

\section{Students Recognized That Peer Teaching Affected Their Knowledge and Perceptions of GMOs}

We obtained information about students' perceptions about the effect of the SLP on their learning through the reflective writing assignments. Undergraduates wrote one- to two-page guided reflections about the teaching experience. Seventy-three percent of students reported in their reflection that the peer-teaching experience had increased their understanding of the concepts they taught. For example, one student wrote, "Overall I had my doubts in the beginning and I didn't truly believe that teaching would help me understand, but as I went on to teach four groups with my partner I developed a good amount of understanding. I could probably talk about GMOs and red/purple tomatoes to someone at [a coffee shop] now."

We identified aspects of the SLP that contributed to undergraduates' learning reported in the reflective writing assignment. As shown in Table 2, 59\% of the students commented that their understanding of the lesson concepts was deepened by the SLP. Students reported that the repetitive nature of the peer-teaching process in the SLP (two classes a day, 2 weeks in a row), enjoyment of the teaching experience, the act of teaching itself, interactions with the high school students, and connections to lecture content were the components that supported their increased understanding of the material. One student specifically stated that the way in which the lesson compared genetic engineering with selective breeding was a key component in understanding: "The images we taught of the genetic history of natural selection versus the process of GMOs actually really helped me to understand." These results suggest that not only did the peer teaching itself contribute to students' learning, but the fact that students had to teach the same material multiple times was an important factor of the SLP that contributed to deeper understanding of the lesson concepts.

Students also reported that the teaching experience changed their perceptions about GMOs. Twenty-four percent specifically wrote that their opinions or perceptions about GMOs were changed through the teaching process. Seventy-three percent of students wrote reasons why their opinions about GMOs had changed in their reflection. The main reasons given for the change in perception were learning that GMOs were not harmful to human health; that GMOs were already in widespread 
TABLE 2. Aspects of the SLP that contributed to student learning as indicated by comments in the reflective writing assignment, listed by category with the percent of students citing each category indicated

\begin{tabular}{|c|c|c|}
\hline Category $^{\mathrm{a}}$ & $\begin{array}{l}\text { Percent of students } \\
\text { with comments in } \\
\text { each category }\end{array}$ & Example \\
\hline $\begin{array}{l}\text { Deeper understanding than } \\
\text { before SLP }\end{array}$ & 59 & $\begin{array}{l}\text { "I really enjoyed the teaching experience because I feel like it really helped me to understand } \\
\text { the concepts even better than I did before." }\end{array}$ \\
\hline Repetition of teaching & 35 & $\begin{array}{l}\text { "My understanding of the curriculum only served to increase as I taught over the course of } \\
\text { our two teaching labs. Any material I was uncomfortable with during the first teaching } \\
\text { session became like second nature by the time I was teaching my last session." }\end{array}$ \\
\hline Enjoyment or confidence & 32 & $\begin{array}{l}\text { "This was also able to help me understand the topics we were teaching better because } \\
\text { studying the script and having to teach and be confident in my teaching helped me } \\
\text { become not only a better student, but a better learner as well." }\end{array}$ \\
\hline Act of teaching & 30 & $\begin{array}{l}\text { "I found that I learned the material much better by teaching it to kids then [sic] when I just } \\
\text { studied it." }\end{array}$ \\
\hline Interactions with students & 16 & $\begin{array}{l}\text { "I learned a lot more about genetics and plant reproduction because the students asked } \\
\text { questions about every concept which caused me to challenge myself to explain each topic } \\
\text { in a way that is coherent and to the point." }\end{array}$ \\
\hline $\begin{array}{l}\text { Connections to lecture } \\
\text { material }\end{array}$ & 10 & $\begin{array}{l}\text { "Overall, I found this experience incredibly enlightening to my Bio } 101 \text { experience as it caused } \\
\text { me to fully implement the concepts taught in lecture and teach them to others, thus } \\
\text { furthering my understanding of them and their importance in science." }\end{array}$ \\
\hline
\end{tabular}

aSome students included more than one category in their comments.

use; the purpose for making GMOs; and how GMOs are made, as shown in Table 3. These results are consistent with changes in undergraduates' perceptions of the risks and benefits of GMOs as determined from their responses to the statement "Genetically engineered crop plants should be a part of our food supply. Do you agree or disagree with this statement? Explain your answer," described earlier.

Eleven percent of students wrote in their reflective writing that their perceptions of GMOs were unchanged, but that they had a deeper understanding of them, while 5\% simply reported that their perceptions were unchanged. These students whose perceptions of GMOs did not change already supported their usage before SLP participation, consistent with an informed perspective that was not changed by class experience. Three students (8\%) reported remaining concerns about GMOs. For example, one student commented, "While I am still concerned about the fact they haven't been around long enough for us to understand the long-term effects of
GMOs, I understand the benefits and the widespread use of them better now."

\section{Behavior Regarding GMO-Related Information Changed over the Course of the Semester}

Our fourth research question asked whether undergraduates acted on their new knowledge and/or attitudes about GMO crops by changing their behavior with regard to obtaining or using GMO-related information. We measured this behavior over the course of the semester using a four-item survey given pre-SLP, post-SLP, and at the end of the semester. Three questions asked about the frequency of obtaining or using GMO-related information, to which students responded on a four-point scale, with options being never, rarely, sometimes, and often (Figure 7). The fourth question was an open-response format and asked students to explain why they had or had not retrieved GMO-related information. The number of students who responded "never" to the first three

TABLE 3. Reasons contributing to changes in undergraduates' opinions and perceptions about GMOs as shown by comments in the reflective writing assignment, listed by category with the percent of students citing each category indicated $(n=37)$

\begin{tabular}{|c|c|c|}
\hline Category & $\begin{array}{c}\text { Percent of } \\
\text { comments in category }\end{array}$ & Example \\
\hline $\begin{array}{l}\text { Not harmful to } \\
\text { human health }\end{array}$ & 24 & $\begin{array}{l}\text { "The teaching experience changed my understanding and perceptions of GMO's [sic] because I } \\
\text { realized that they are not necessarily bad for you. I also learned that there aren't actually any } \\
\text { valid studies proving them to having [sic] harmful effects on health." }\end{array}$ \\
\hline $\begin{array}{l}\text { Widespread use in } \\
\text { agriculture }\end{array}$ & 16 & $\begin{array}{l}\text { "Teaching the GMO curriculum greatly improved my understanding of the concepts with many of } \\
\text { the facts being presented being new for myself especially in the field of how widespread } \\
\text { GMOs are already in US agriculture and food markets." }\end{array}$ \\
\hline $\begin{array}{l}\text { Understanding } \\
\text { purpose }\end{array}$ & 16 & $\begin{array}{l}\text { "I realized how important crop improvement was to our everyday life. I began to see that } \\
\text { genetically modifying crops does not have to be a bad thing, and it is actually very helpful to } \\
\text { farmers today." }\end{array}$ \\
\hline $\begin{array}{l}\text { Understanding how } \\
\text { GMOs are made }\end{array}$ & 8 & $\begin{array}{l}\text { "I was also better able to understand the reasoning behind using GMOs. The images we taught of } \\
\text { the genetic history of natural selection versus the process of GMOs actually really helped me } \\
\text { to understand." }\end{array}$ \\
\hline
\end{tabular}




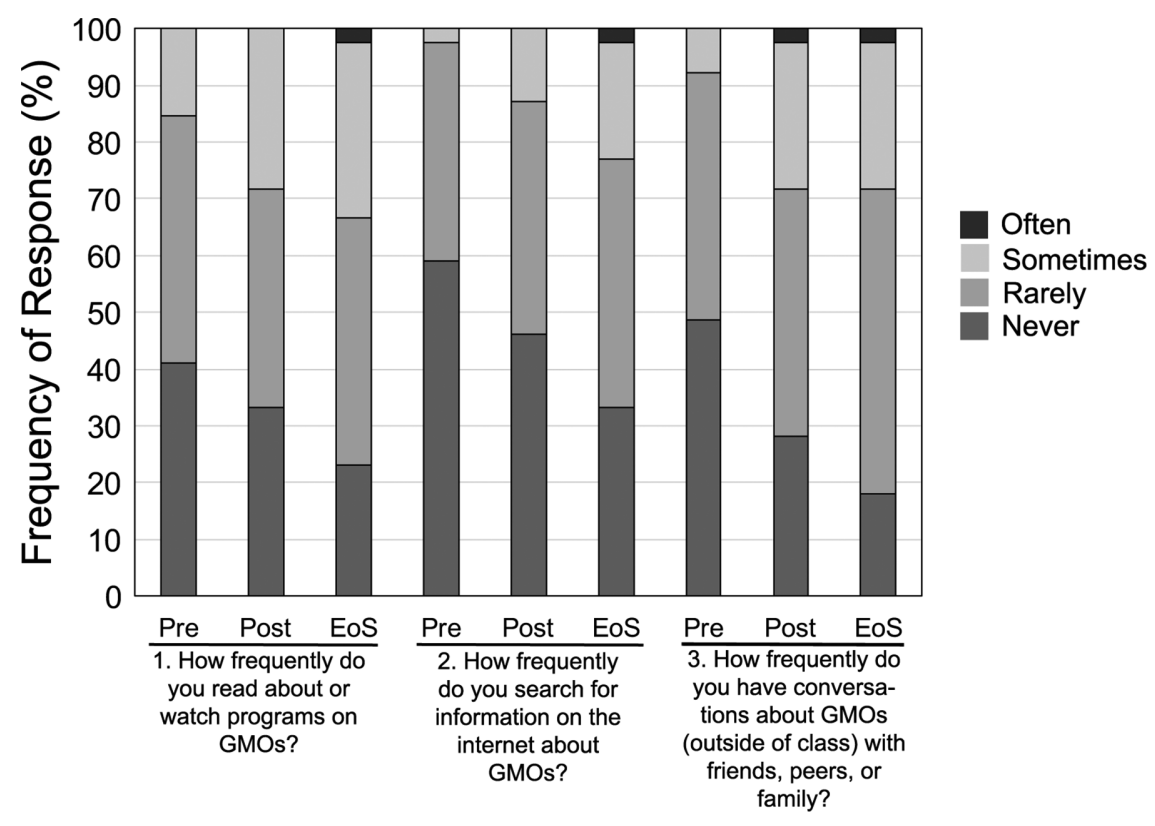

FIGURE 7. Undergraduate students' responses to questions about the frequency of their behavior in obtaining or discussing GMO-related information, measured pre-SLP (Pre), post-SLP (Post), and at the end of the semester (EoS). ( $n=37)$. body. From reading and watching about GMOs and learning about them in this class, I think my skepticism about GMOs comes from my skepticism about processed foods in general, not the technology behind GMOs."

"I've looked it up over self interest because I was curious about the legal state of GMO labeling in our country and what different political parties think about labeling GMO's [sic]."

"I have [looked up GMOs on the Internet] just out of curiosity of the health benefits or health consequences of digesting them."

"I heard conflicting views about GMOs and I wanted to see what all the fuss was about."

Student comments post-SLP also show that some students were talking about GMOs with their peers or family members more frequently than previously. questions decreased between the pre-SLP and post-SLP assessments and between the post-SLP and end-of-semester assessments for all three questions, suggesting that students' retrieval and use of GMO-related information continued past the SLP.

Friedman's test followed by a Wilcoxon signed-rank analysis was used to determine significant differences in distribution of responses before and after SLP participation. We found significant changes in how often students searched for information about GMOs on the Internet $(Z=-2.07 ; p=0.039)$ and had conversations about GMOs outside class $(Z=-3.55 ; p=0.0001)$ between the time before the SLP and post-SLP. We also found significant changes in how often students read about or watched programs about GMOs $(Z=-2.85 ; p=0.004)$, searched for information about GMOs on the Internet $(Z=-3.14 ; p=0.002)$, and had conversations about GMOs outside class $(Z=-3.52$; $p=0.0001$ ) between the time before the SLP and the end of the semester. The results showed that student behavior related to obtaining and discussing GMO-related information increased after the SLP and stayed high throughout the semester. This finding is important, as it indicates that this SLP helped us achieve student engagement in the topic beyond the class, a key step in creating scientifically literate citizens.

These results are supported by the answers to the open-response question, in which students explained why they learned or did not learn about GMOs. The most frequent response was that students did not learn about or talk about GMOs, because they were not interested in them. However, post-SLP answers to the open-response question reveal that some students became interested in the topic after SLP participation. For example:

"I have read and watched about GMO technology because I want to be informed about what I am putting into my
"My dad asked me if I knew anything about GMOs and I told him about them."

"I have explained the science of GMOs since teaching at the public high schools. I was able to apply what I learned and discussed it with my friends to help them understand some of the foods we eat and to help them understand the misconceptions regarding GMOs."

"After this lab I know a lot more about GMOs and I have explained it to others, but before this, no."

These results suggest that, although a change to a more positive attitude was not enough to increase interest in the topic for the majority of students, some students were motivated to learn more about GMOs.

\section{DISCUSSION}

This study examined how a peer-teaching SLP affected non-science major undergraduates' opinions about whether GMOs should be used as food, their perceptions about the risks and benefits of the technology, and their knowledge of GMOs and the use of GMOs in agriculture. We found that, after students participated in the peer-teaching program, their knowledge about GMOs increased and their perceptions and opinions about the use of GMOs shifted to be more positive. Our findings showed statistically significant correlations between students who perceived GMOs as harmful and those who had incorrect knowledge about GMOs and between those who perceived GMOs as harmful and who were opposed to the use of GMOs. These results suggest that lack of understanding about GMOs contributed to students' negative opinions about their use. These results are similar to other studies showing that accurate knowledge is associated with a positive attitude toward GMOs 
and other types of biotechnology, either by measuring attitude and correlating that with a college student's major (Fonseca et al., 2012; Tegegne et al., 2013; Bhavsar et al., 2015) or after an intervention (Santerre and Machtmes, 2002; Klop et al., 2010; Heddy et al., 2016). To our knowledge, no study has used peer teaching as the form of intervention to explore changes in attitude toward a socioscientific issue. We have already established the success of this model in helping students achieve cognitive gains in understanding genetics (Chrispeels et al., 2014). We propose that cross-age peer teaching is also an effective method for helping students develop informed opinions about socioscientific issues.

Our study provided valuable insights into the type of knowledge that students have about GMOs before formal instruction. Aside from incorrect knowledge about the safety of GMOs, which was eliminated after peer teaching, we found that students tended to either confuse features of GMOs with features of modern agriculture or describe GMOs as a type of "magic bullet" that can solve all food security problems. As most students do not have a complete grasp of modern agricultural methods (Sohan et al., 2002), it is not surprising that students would have this lack of understanding. An instructional path to decreasing both types of misunderstandings could be to more clearly distinguish genetic engineering advances from those of modern agriculture. Explaining genetic engineering in the context of modern agriculture would also help students understand that genetic engineering is yet one more tool that breeders and plant scientists use to solve agricultural problems, not an agricultural panacea. This approach has been successfully used by other researchers to increase knowledge, affect attitudes, and improve reasoning about the use of GMOs (Santerre and Machtmes, 2002; Seethaler and Linn, 2004).

Along with other studies that used interventions to examine how attitudes toward GMOs change when students are presented with the science of genetic engineering (Santerre and Machtmes, 2002; Klop et al., 2010; Heddy et al., 2016), our study shows that knowledge and attitude change occur when students learn about genetic engineering through a peer-teaching format as the form of intervention. Specific aspects of our SLP that contributed to these changes are the peer-teaching itself, the repetitive nature of the teaching experience, enjoyment of the teaching experience, and interactions with the high school students. Learning about how GMOs are made, their purpose, and the fact that they are already in widespread use in agriculture contributed to undergraduates' changed attitudes. Questions that have not yet been explored are whether those attitude changes persist, and whether they affect behavior. Our finding that the frequency with which undergraduates obtained and used information about GMOs outside class increased over the course of the semester is interesting, because it suggests that some students may have acted on their increased understanding of GMOs and/or their changed opinions of GMOs by learning more about the topic on their own or discussing it with their peers. Open-response comments indicated that students became more interested in the subject and read or acquired additional information about GMOs separate from class experiences. We found significant differences between the pre-SLP and post-SLP assessments in how often students read about or watched programs about GMOs and searched for information on the Internet, and this increase in behavior continued to the end of the semester. This suggests both a more long-term interest in learning about this biotechnology and individual motivation that is independent of class expectations or teaching needs. One possible conclusion from this finding is that these students may be more likely to search for information on their own to make informed decisions when voting on GMO-related ballot measures or making decisions as consumers.

Examining the components of our peer-teaching model through the lens of the different psychological theories behind peer teaching may explain the observed results. For example, features of our SLP support the conditions of autonomy, competence, and relatedness, the three psychological conditions that must be fulfilled for intrinsic motivation, according to self-determination theory (Deci and Ryan, 1985). Our results showing an increase in knowledge about GMOs, together with student comments indicating that the teaching increased their knowledge, support the condition of competence. Autonomy was built into the program in terms of the teaching structure. Undergraduates were taught the activities and given a script with questions, but could adapt the flow of activities to fit their students' needs. Comments in the reflection writing assignments from this cohort and previous years indicated that undergraduates felt confident about making changes to the flow of activities when they taught. Undergraduates also had several opportunities for relatedness, including with their lab partner and with the students they taught. Comments in the reflection suggest that interactions with and connections to high school students contributed to undergraduates' learning of the lesson material.

Intrinsic motivation occurs when students' goals are task focused rather than performance focused; that is, when students are concerned with mastering the material as opposed to getting a good grade or besting other students (Deci and Ryan, 1985). In our SLP, undergraduates are not graded on their teaching, which may encourage task goal setting and reduce performance goal setting. Students had to master the material sufficiently to explain the information to high school students and answer their questions, and this goal may have involved intrinsic motivation.

Students can also be motivated when they feel they have a stake in the outcome or are emotionally involved in the topic (Dole and Sinatra, 1998). The desire to come across as knowledgeable and professional in front of the high school students gives undergraduates a stake in the outcome of their teaching and may motivate them to learn and process the information at a deep level. This desire may be especially true for non-science majors, who may feel less confident in their skills as teachers of science concepts. The opportunity to adopt the teaching role may also have contributed to undergraduates' learning of the material, as suggested by some students' comments in the reflection writing.

Finally, our peer-teaching model had undergraduates teach in pairs in the high schools. Each pair trained together, practiced together outside class, and taught together. Student comments indicated that working together with a partner was an important part of the SLP and contributed to the confidence students felt in teaching. This component of the SLP model may have also supported the undergraduates' conceptual learning. Decades of research on cooperative or team learning have shown that working with others can enhance student learning 
(e.g., Slavin and Karweit, 1981; Klionsky, 1998; Johnson et al., 2007). We suggest that working in pairs is an important consideration for faculty who wish to establish this type of cross-age peer-teaching program committed to providing service and enhancing knowledge and understanding of challenging science concepts.

Together, the results presented in this paper suggest that students can become more informed about socioscientific issues as a result of peer-teaching activities in non-science major classes. The process of peer teaching a curriculum designed to help them understand how GMOs are made and how they are used in agriculture informed students' understanding and changed their perception of GMOs used as a source of food. The biggest knowledge changes were in understanding the similarities and differences between GMO technology and selective breeding, suggesting that teaching this complex topic can have profound effects on students' understanding. Our results suggest that, when students understand how much humans have already manipulated the genomes of plants through breeding, they are more comfortable with the targeted modification of plant genomes by adding individual genes through genetic modification.

\section{ACKNOWLEDGMENTS}

This study was funded by a Plant Biology Learning Objectives, Outreach Materials, and Education grant from the Education Foundation of the American Society of Plant Biologists and by the National Science Foundation (IOS-1558046).

\section{REFERENCES}

Allen, V. I., \& Feldman, R. S. (1972). Learning through tutoring: Low-achieving children as tutors. Journal of Experimental Education, 42, 1-5.

Allen, V. I., \& Feldman, R. S. (1976). Children as teachers. New York: Academic Press.

Annis, L. F. (1983). The processes and effects of peer tutoring. Human Learning, 2, 39-47.

Bargh, J. A., \& Schul, Y. (1980). On the cognitive benefits of teaching. Journal of Educational Psychology, 72, 593-604

Beachboard, M. R., Beachboard, J. C., Li, W., \& Adkison, S. R. (2011). Cohorts and relatedness: Self-determination theory as an explanation of how learning communities affect educational outcomes. Research in Higher Education, 52, 853-874.

Begley, G. S. (2013). Making connections: Service-learning in introductory cell and molecular biology. Journal of Microbiology and Biology Education, 14, 213-220

Benware, C. A., \& Deci, E. L. (1984). Quality of learning with an active versus passive motivational set. American Educational Research Journal, 21, 755-765.

Bhavsar, H., Tegegne, F., Ekanem, E., \& Singh, S. P. (2015). Awareness and attitudes of Tennessee consumers towards agricultural biotechnology: Survey results. Journal of Food Research, 4, 97-104.

Bredahl, L. (2001). Determinants of consumer attitudes and purchase intentions with regard to genetically modified foods-results of a cross-national survey. Journal of Consumer Policy, 24, 23-61.

Burgess, A., McGregor, D., \& Mellis, C. (2014). Medical students as peer tutors: A systematic review. BMC Medical Education, 14, 115-122.

Chrispeels, H. E., Klosterman, M. L., Martin, J. B., Lundy, S. R., Watkins, J. M., Gibson, C. L., \& Muday, G. K. (2014). Undergraduates achieve learning gains in plant genetics through peer teaching of secondary students. CBE-Life Sciences Education, 13, 641-652.

Cohen, P., Kulik, J., \& Kulik C. (1982). Educational outcomes of tutoring: A meta-analysis of findings. American Educational Research Journal, 19, 237-248.
Corbin, J., \& Strauss, A. (2008). Basics of qualitative research (3rd ed). Los Angeles: Sage.

Dawson, V., \& Soames, C. (2006). The effect of biotechnology education on Australian high school students' understandings and attitudes about biotechnology processes. Research in Science and Technological Education, 24, 183-198.

Deci, E. L., \& Ryan, R. M. (1985). Intrinsic motivation and self-determination in human behavior. New York: Plenum.

Dole, J. A., \& Sinatra, G. M. (1998). Reconceptualizing change in the cognitive construction of knowledge. Educational Psychologist, 33, 109-128.

Dori, Y. J., Tal, R. T., \& Tsaushu, M. (2003). Teaching biotechnology through case studies - can we improve higher order thinking skills of nonscience majors? Science Education, 87, 767-793.

Esson, J. M., Stevens-Truss, R., \& Thomas, A. (2005). Service-learning in introductory chemistry: Supplementing chemistry curriculum in elementary schools. Journal of Chemical Education, 82, 1168-1173.

European Commission. (2001). Europeans, science, and technology. Eurobarometer, 55, 2. Retrieved October 5, 2017, from http://ec.europa.eu/ research/press/2001/pr0612en-report.pdf

Finke, M. S., \& Kim, H. (2003). Attitudes about genetically modified foods among Korean and American college students. AgBioForum, 6, 191197.

Fiorella, L., \& Mayer, R. E. (2013). The relative benefits of learning by teaching and teaching expectancy. Contemporary Educational Psychology, 38, 281-288.

Fonseca, M. J., Costa, P., Lencastre, L., \& Tavares, F. (2012). Multidimensional analysis of high-school students' perceptions about biotechnology. Journal of Biological Education, 46, 129-139.

Galbraith, J., \& Winterbottom, M. (2011). Peer-tutoring: What's in it for the tutor? Educational Studies, 37, 321-332.

Gaustad, J. (1993). Peer and cross-age tutoring. ERIC Digest, 79. Retrieved from ERIC (ED354608).

Glover, S. R., Sewry, J. D., Bromley, C. L., Davies-Colman, M. T., \& Hlengwa, A. (2014). The implementation of a service-learning component in an organic chemistry laboratory course. Journal of Chemical Education, 90, $578-583$.

Guay, F., Ratelle, C. F., \& Chanal, J. (2008). Optimal learning in optimal contexts: The role of self-determination in education. Canadian Psychology. 49, 233-240.

Heddy, B. C., Danielson, R. W., Sinatra, G. M., \& Graham, J. (2016). Modifying knowledge, emotions and attitudes regarding genetically modified foods. Journal of Experimental Education, doi: 10.1080/00220973 .2016 .1260523

Johnson, D. W., Johnson, R. T., \& Smith, K. (2007). The state of cooperative learning in postsecondary and professional settings. Educational Psychology Review, 19, 15-29.

Juel, C. (1991). Cross-age tutoring between student athletes and at-risk children. Reading Teacher, 45, 178-186.

Karyan, S., \& Gathercoal, P. (2005). Assessing service-learning in teacher education. Teacher Education Quarterly, 32, 79-92.

Klionsky, D. J. (1998). A cooperative learning approach to teaching introductory biology: Experimenting with an innovative teaching style at the University of California, Davis. Journal of College Science Teaching, 27, 334-338.

Klop, T., Severiens, S. E., Knippels, M.-C. P. J., van Mil, M. H. W., \& Ten Dam G. T. M. (2010). Effects of a science education module on attitudes towards modern biotechnology of secondary school students. International Journal of Science Education, 32, 1127-1150.

Klosterman, M. L., Chrispeels, H. E., Reagan, B. R., Lundy, S. R., Browne, C. L., \& Muday, G. K. (2014). That's a tomato? Using a familiar food to explore genetic variation. Science Activities, 51, 1-16.

Korner, M., \& Hopf, M. (2015). Cross-age peer tutoring in physics: Tutors, tutees, and achievement in electricity. International Journal of Science and Mathematics Education, 13, 1039-1063.

Levesque-Bristol, C., Knapp, T. D., \& Fisher, B. J. (2010). The effectiveness of service-learning: It's not always what you think. Journal of Experiential Education, 33, 208-224 
McHughen, A. (2013). GM crops and foods. What do consumers want to know? GM Crops and Food: Biotechnology in Agriculture and the Food Chain, 4, 172-182.

McHughen, A., \& Wager, R. (2010). Popular misconceptions: Agricultural biotechnology. New Biotechnology, 27, 725-728.

Millar, R. (2006). Twenty first century science: Insights from the design and implementation of a scientific literacy approach in school science. International Journal of Science Education, 28, 1499-1521.

Minnaert, A., Boekaerts, M., \& DeBrabander, C. (2007). Autonomy, competence, and social relatedness in task interest within project-based education. Psychology Reports, 101, 574-586.

Mohapatra, A. K., Priyadarshini, D., \& Biswas, A. (2010). Genetically modified food: Knowledge and attitude of teachers and students. Journal of Science Education and Technology, 19, 489-497.

National Research Council. (2012). Discipline-based education research: Understanding and improving learning in undergraduate science and engineering. Washington, DC: National Academies Press.

Niemiec, C. P., \& Ryan R. M. (2009). Autonomy, competence, and relatedness: Applying self-determination theory to educational practice. Theory and Research in Education, 7, 133-144

Pintrich, P. R. (2003). A motivational science perspective on the role of student motivation in learning and teaching contexts. Journal of Education Psychology, 95, 667-686.

Robinette, M. S., \& Noblet, R. (2009). Service-learning in entomology: Teaching, research, and outreach domestically and abroad. Journal of Higher Education Outreach and Engagement, 13, 135-153.

Robinson, D. R., Schofield, J. W., \& Steers-Wentzell, K. L. (2005). Peer and cross-age tutoring in math: Outcomes and their design implications. Educational Psychology Review, 17, 327-362.

Roscoe, R. D., \& Chi, M. T. H. (2007). Understanding tutor learning: Knowledge-building and knowledge-telling in peer tutors' explanations and questions. Review of Educational Research, 77, 534-574.

Ryan, R. M., \& Deci, E. L. (2000). Self-determination theory and the facilitation of intrinsic motivation, social development, and well-being. American Psychologist, 55, 68-78.

Sadler, T. D. (2004). Moral and ethical dimensions of socioscientific decision-making as integral components of scientific literacy. Science Educator, 13, 39-48.
Santerre, C. R., \& Machtmes, K. L. (2002). The impact of consumer food biotechnology training on knowledge and attitude. Journal of American College Nutrition, 21, 174S-177S.

Seethaler, S., \& Linn, M. (2004). Genetically modified food in perspective: An inquiry-based curriculum to help middle school students make sense of tradeoffs. International Journal of Science Education, 26, 1765-1785.

Slavin, R. E., \& Karweit, N. L. (1981). Cognitive and affective outcomes of an intensive student team learning experience. Journal of Experimental Education, 50, 29-35.

Sohan, D. E., Waliczek, T. M., \& Briers, G. E. (2002). Knowledge, attitudes, and perceptions regarding biotechnology among college students. Journal of Natural Resources and Life Sciences Education, 31, 5-11.

Tegegne, F., Azai, A. H., Bhavsar H., \& Wiemers, R. (2013). Awareness of and attitudes towards biotechnology by Tennessee State University students with different backgrounds and majors. Journal of Biotechnology Research, 5, 16-23.

Ten Cate, O., \& Durning, S. (2007). Dimensions and psychology of peer teaching in medical education. Medical Teacher, 29, 546-552.

Tessier, J. (2007). Small-group peer teaching in an introductory biology classroom. Journal of College Science Teaching, 36, 64-69.

Topping, K. J. (1996). The effectiveness of peer tutoring in further and higher education: A typology and review of the literature. Higher Education, 32, 321-345.

Topping, K. J. (2005). Trends in peer learning. Journal of Experimental Educational Psychology, 25, 631-645.

Wingenbach, G. J., Rutherford, T. A., \& Dunsford, D. W. (2003). Agricultural communications students' awareness and perceptions of biotechnology issues. Journal of Agricultural Education, 44, 80-93.

Witzig, S. B., Freyermuth, S. K., Siegel, M. A., Izci, K., \& Pires, J. C. (2013). Is DNA alive? A study of conceptual change through targeted instruction. Research in Science Education, 43, 1361-1375.

Wohl, J. B. (1998). Consumers' decision-making and risk perceptions regarding foods produced with biotechnology. Journal of Consumer Policy, 21 387-404.

Yu, T-C., Wilson, N. C., Singh, P. P., Lemanu, D. P., Hawken, S. J., \& Hill, A. G. (2011). Medical students-as-teachers: A systematic review of peer-assisted teaching during medical school. Advances in Medical Education and Practice, 2, 157-172 